\title{
Metode Saving Matrix Dalam Penentuan Rute Distribusi Premium Di Depot SPBU Bandung
}

\author{
Edi Supardi, Ruben Chandra Sianturi \\ ${ }_{1}$ Prodi D3 Administrasi Logistik, Politeknik Pos Indonesia \\ email: edisupardi@poltekpos.ac.id \\ ${ }_{2}$ Prodi D3 Administrasi Logistik, Politeknik Pos Indonesia \\ email: rubenchandrasianturi@gmail.com
}

\begin{abstract}
Abstrak
Beberapa masalah yang ada di PT. Depot Pertamina Bandung dalam mendistribusikan produk premium ke SPBU di Bandung adalah tingginya permintaan premium tidak diimbangi dengan ketersediaan jumlah kendaraan serta kapasitas truk tangki yang memadai, dan inkonsistensi dalam jadwal distribusi setiap hari, dan kurangnya layanan distribusi standar yang jelas. Oleh karena itu, penelitian ini bertujuan mengatur rute dan jadwal distribusi serta menentukan kapasitas dan jumlah truk tangki yang efektif dan efisien agar menguntungkan perusahaan. Dalam penelitian ini, penentuan metode penghematan matriks yang berguna untuk menyelesaikan masalah transportasi dan distribusi. Berdasarkan perhitungan dengan menggunakan metode saving matrix, maka distribusi proposal ini dapat diberikan sebanyak 7 dalam tiga tahap pengiriman sehingga setiap pompa bensin tidak akan kekurangan pasokan bahan bakar. Berhasil mengurangi biaya transportasi dari Rp 1.127.392 menjadi Rp 861.733. Dalam distribusi premium di Bandung PT. Depot Pertamina Bandung yang awalnya menggunakan 6 truk tangki mampu dirampingkan menjadi 4 tangki.
\end{abstract}

Kata Kunci: Saving Matrix and Distribution.

\section{PENDAHULUAN}

Dalam dunia bisnis, transportasi dan distribusi merupakan dua komponen yang mempengaruhi keunggulan kompetitif suatu perusahaan karena penurunan biaya transportasi dapat meningkatkan keuntungan perusahaan secara tidak langsung. Salah satu cara untuk menurunkan biaya transportasi adalah dengan mengefisienkan sistem distribusi dan penggunaan moda transportasi yang ada. Efisiensi sistem distribusi ini juga dapat dilakukan dengan menentukan rute pendistribusian untuk meminimalkan total jarak tempuh, dan lama perjalanan sehingga dapat mengoptimalkan penggunaan kapasitas serta jumlah kendaraan.

PT. Pertamina Depot Bandung dalam mendistribusikan produk premiumnya ke SPBU yang ada di Bandung, memiliki Beberapa permasalahan salah satu diantaranya adalah tingginya jumlah biaya transportasi yang harus ditanggung oleh perusahaan dan belum adanya standar rute distribusi yang jelas sehingga SPBU harus menunggu kiriman pasokan BBM cukup lama dari truk tangki yang sedang mendistribusikan ke SPBU lain karena truk harus pulang terlebih dahulu ke depot untuk dilakukan pengisian ulang dan ketidakkonsistenan jadwal pendistribusian di setiap harinya.

Penelitian dibuat dengan tujuan untuk melakukan pengaturan atas rute dan jadwal pendistribusian serta menentukan kapasitas dan jumlah kendaraan truk tangki yang yang mampu meminimalkan lama perjalanan, dan biaya transportasi melalui metode saving matrix dengan obyek penelian di PT. Pertamina Depot dan SPBU Kota Bandung.

Penelitian dengan menggunakan metode saving matrix telah banyak digunakan dalam pemecahan masalah distribusi, namun penelitian terkait distribusi premium di Kota Bandung dengan metode saving matrix, belum dilakukan. Manfaat yang diharapkan dari penelitian ini adalah mengetahui jadwal pendistribusian premium yang efektif dan efisien sehingga bisa mempercepat pengiriman, 
meminimasi biaya transportasi, dan meningkatkan keuntungan perusahaan, serta mampu menentukan kapasitas dan jumlah kendaraan truk tangki yang tepat sesuai jumlah permintaan premium.

\section{METODE PENELITIAN}

\subsection{Distribusi}

\subsubsection{Pengertian Distibusi}

Distribusi berakar dalam bahasa inggris distribution yang berarti pelayanan, sedangkan kata dasarnya to distribute, berdasarkan Kamus Inggris Indonesia yang berarti membagikan, menyalurkan, menyebarkan dan menangani. Distribusi juga dapat diartikan sebagai pergerakan atau perpindaahn barang atau jasa dari sumber sampai ke konsumen akhir, konsumen atau pengguna, melalui saluran distribusi (distribution channel) dan gerakan pembayaran dalam arah yang berlawanan, sampai ke produsen asli atau pemasok (Subagyo, 2000)

Distribusi sering digambarkan sebagai satu dari bauran pemasaran (4P) yaitu price, place, product, promotion dengan menempatkan produk pada tempat yang sesuai untuk pembelian (Kotler, 2000). Manajemen distribusi dan transportasi dapat disebut juga sebagai manajemen logistik atau distribusi fisik. Logistik modern dapat didefenisikan sebagai proses pengelolaan yang strategis terhadap pemindahan dan penyimpanan barang, suku cadang dan barang jadi dari para supplier, diantara fasilitas-fasilitas perusahaan dan kepada para pelanggan (Bowersox, 2006). Kegiatan transportasi dan distribusi bisa dilakukan oleh perusahaan manufaktur dengan membentuk bagian distribusi atau transportasi tersendiri atau diserahkan ke pihak ketiga. Dalam upayanya untuk memenuhi tujuantujuan diatas, siapapun yang melaksanakan (internal perusahaan atau mitra ketiga), manajemen distribusi dan transportasi pada umumnya melakukan sejumlah fungsi dasar (Pujawan, 2006). Menentukan mode transportasi yang akan digunakan, melakukan konsolidasi informasi dan pengiriman, melakukan penjadwalan dan penentuan rute pengiriman, memberikan pelayanan nilai tambah, menyimpan persediaan, menangani pengembalian .

\subsubsection{Prosedur Saluran Distribusi}

Prosedur menentukan saluran (Suntoyo, Prosedur Saluran Distribusi, 2013) distribusi pada umumnya sebagai berikut:

a. Melakukan analisis terhadap produk yang akan dipasarkan untuk menetukan sifat-sifat dan gunanya.

b. Menentukan sifat-sifat produk dan luasnya pasar.

c. Melakukan market survey untuk mengetahui pendapat-pendapat pembeli dan perantara mengenai saluran distribusi yang dipergunakan oleh pesaing.

\subsubsection{Fungsi Distribusi}

Pada pokoknya fungsi-fungsi pemasaran dilaksanakan yaitu saluran distribusi dapat dikelompokkan menjadi tiga fungsi (Swasta, 2012).

1. Fungsi pertukaran

Pada fungsi pertukaran dibedakan menjadi 3 macam, yaitu pembelian, penjualan, pengembalian resiko.

a. Pembelian

Fungsi pembelian meliputi usaha memilih barang - barang yang dibeli untuk dijual kembali atau untuk digunakan sendiri dengan harga, pelayanan dari penjual dan kualitas tertentu

b. Penjualan

Fungsi penjualan dilakukan oleh pedagang besar sebagai alat pemasaran bagi produsennya. Fungsi ini sangat penting karena bertujuan menjual barang atau jasa yang diperlukan sebagai sumber pendapatan untuk menutup semua biaya untuk memperoleh laba.

c. Pengambilan resiko

Fungsi pengambilan resiko merupakan fungsi menghindari dan mengurangi resiko terhadap semua masalah dalam pemasaran, sehingga akan melibatkan beberapa fungsi yang lain. Dalam penyaluran barang - barang biasanya pedagang besar memberikan jaminan tertentu baik kepada pengecer maupun produsennya.

2. Fungsi penyediaan fisik

Ada empat macam fungsi yang termasuk dalam penyediaan fisik diantaranya:

a. Pengumpulan

Sebagai alat penyaluran perantara melakukan fungsi pengumpulan barang - barang dari beberapa sumber atau beberapa macam barang dari sumber yang sama.

b. Penyimpanan

Fungsi ini merupakan faedah waktu karena melakukan penyesuaian antara penawaran dengan permintaannya.

c. Pemilihan

Fungsi ini dilakukan oleh penyalur dengan cara mengolonggolongkan, memeriksa, dan menentukan jenis barang yang disalurkan.

d. Pengangkutan

Fungsi ini, merupakan fungsi pemindahan barang dari tempat barang dihasilkan ke tempat barang di konsumsikan.

3. Fungsi penunjang

Fungsi ini terbagi menjadi empat macam, yaitu pelayanan sesudah pembelian, pembelanjaan, penyebaran informasi, dan koordinasi saluran.

a. Pelayanan sesudah pembelian 
Memberikan jaminan terhadap kenyamanan penggunaan barang tersebut setelah dibeli oleh konsumen.

b. Pembelanjaan

Kedua belah pihak baik konsumen maupun produsen memerlukan sumber pembelanjaan yang bisa di dapat dari penjual, penyedia dengan cara membayar kredit.

c. Penyebaran informasi

Berbagai macam informasi diperlukan dalam penyaluran barang karena dapat membantu untuk menentukan sumbernya.

d. Koordinasi saluran

Fungsi ini sangat berkaitan dengan fungsi penyebaran informasi dan apabila terjadi komunikasi yang baik antar elemen maka akan sangat memudahkan di dalam pelaksanaan penyaluran.

\subsection{Metode Saving Matrix}

Saving Matrix merupakan metode yang digunakan untuk menentukan jarak, rute, waktu atau ongkos dalam pelaksanaan pengiriman barang dari perusahaan kepada konsumen. Metode ini bertujuan agar pengiriman barang yang sesuai pesanan konsumen dapat dilakukan dengan cara yang efektif dan efisien, sehingga perusahaan dapat menghemat biaya, tenaga, dan waktu pengiriman (Istantiningrum, 2010) Adapun langkah-langkah dalam menggunakan metode Saving Matrix adalah sebagai berikut :

1. Menentukan Matriks Jarak

Penentuan jarak ini dimulai dari jarak setiap lokasi ke lokasi lainnya. Penentuan jarak ini dilihat dari aplikasi Google Maps untuk membantu pencarian jarak terhadap tempat tempat tersebut yang saling berkaitan. Penentuan jarak

2. Menghitung matriks jarak

Penghitungan matriks jarak ini diasumsikan bahwa tempat - tempat akan dilewati oleh satu alat angkut secara langsung. Penghitungan matriks jarak ini, dilihat dari baris dikali kolom, sehingga mendapat jarak yang akan ditentukan.

3. Menganalisa matriks dengan metode saving matrix

Matriks jarak yang sudah ada, akan dianalisis setiap rutenya untuk dapat dihitung rute yang akan dipilih. Menganalisa matriks jarak dengan metode saving matriks ini menggunakan matriks jarak pada setiap kantor pos dengan rumus sebagai berikut :

$$
\mathrm{S}_{\mathrm{ij}}=\mathrm{d}_{0 \mathrm{i}}+\mathrm{d}_{\mathrm{j} 0}-\mathrm{d}_{\mathrm{ij}}
$$

Sumber: (Supriadi, 2017)

Gambar II. 1 Rumus Matriks Jarak

Berdasarkan rumus diatas :

$\mathrm{S}_{\mathrm{ij}}=$ jarak titik awal dan tujuan

$\mathrm{d}_{0 \mathrm{i}}=$ jarak depot tujuan awal

$\mathrm{d}_{\mathrm{j} 0}=$ jarak depot tujuan akhir

Penghitungan matriks jarak ini akan mendapat matriks jarak yang baru dengan jarak yang sudah dihitung. Setelah adanya matriks jarak dengan metode saving matriks, maka akan ditung beban angkutan untuk setiap rute yang akan direkomendasikan tersebut. Pertama, tentukan kapasitas pada setiap alat angkut untuk membawa beban pada setiap pendistribusian kiriman. Kedua, membuat rute dengan penghematan dan mencari nilai tertinggi pada matriks jarak metode saving matriks untuk menjadi rute pertama. Setelah mendapat nilai tertinggi di matriks jarak metode saving matriks, maka akan dihitung kapasitas yang akan kirim ke pos tersebut hingga rute tersebut tidak melebihi kapasitas dari alat angkut mobilnya. Jika pada cabang belum dapat memenuhi kapasitas dari alat angkut, akan dipilih kembali nilai tertinggi selanjutnya untuk dimasukkan kedalam rute pertama tadi, hingga memenuhi atau tidak melebihi dari kapasitas alat angkut mobil tersebut. Jika sudah terpenuhi, maka rute pertama sudah dapat. Ketiga, menentukan kembali rute kedua dan rute berikutnya dengan jalan yang sama yaitu mencari niai tertinggi pada matriks jarak metode saving matriks hingga memenuhi atau tidak melebihi kapasitas alat angkut mobil. Setelah semua cabang yang ada sudah masuk dalam rute, maka penghitungan sudah selesai. Pada penghitungan ini, jarak dari cabang ke depot diabaikan.

1.Membuat rute dengan metode Nearest Neighbor. Nearest Neighbor, prosedur ini dimulai dari penentuan rute kendaraan ke konsumen yang memiliki jarak yang paling dekat. juga prosedur yang menentukan rute kendaraan ke konsumen dengan tempat yang paling terdekat. Setelah mendapat rute dari perhitungan kapasitas alat mobil angkut dengan menggunakan matriks jarak metode saving matriks, selanjutnya membuat rute yang diplih untuk di analisa dengan menggunakan metode Nearest Neighbor. Metode Nearest Neighbor ini akan menggunakan matiks jarak saja, buka matriks jarak metode saving matriks. Penghitungan metode ini akan dimulai dengan jarak 0 dari Depot hingga semua cabang yang ada pada rute kapasitas barang masuk pad arte 
tersebut dengan membandingkan setiap perjalanan dengan jarak yang paling pendek. Setelah semua pos masuk pada rute pertama, maka akan dilanjutkan dengan penghitungan rute selanjutnya dengan cara yang sama.

2.Membuat rute dengan metode Farthest Insertion Farthest Insertion, prosedur ini dimulai dari penentuan rute kendaraan ke konsumen yang memiliki jarak yang paling jauh, juga prosedur yang menentukan rute kendaraan ke konsumen dengan tempat yang paling terjauh. Setelah mendapat rute dari perhitungan kapasitas alat mobil angkut dengan menggunakan matriks jarak metode saving matriks, selanjutnya membuat rute yang dipilih untuk di analisa dengan menggunakan metode Farthest Insertion. Metode Farthest Insertion ini akan menggunakan matiks jarak saja, buka matriks jarak metode saving matriks. Penghitungan metode ini akan dimulai dengan jarak 0 dari Depot hingga semua cabang yang ada pada rute kapasitas barang masuk pada rute tersebut dengan membandingkan setiap perjalanan dengan jarak yang paling jauh. Setelah semua cabang masuk pada rute pertama, maka akan dilanjutkan dengan penghitungan rute selanjutnya dengan cara yang sama.

3.Menghitung perbandingan bahan bakar yang terpakai.

Perhitungan bahan bakar akan menunjukkan biaya bahan bakar yang diperlukan untuk pendistribusian paket. Penghitungan ini akan membandingkan pemakaian bahan bakar bensin antara rute yang akan direkomendasikan dengan rute yang sudah ada sebelumnya dengan menghitung bahan bakar yang akan dikonsumsi pada setiap jarak rute yang ada.

\subsection{Metode Penelitian}

\subsubsection{Proses Pengambilan Data}

Data permintaan yang digunakan adalah dengan menggunakan data masa lalu diambil selama 3(tiga) bulan di setiap SPBU dari bulan Januari 2020 hingga maret 2020. Untuk data jarak wilayah menggunakan data sekunder dengan menghitung jarak antar depot dengan SPBU yang tersebar luas di kota Bandung sebanyak 7 SPBU.

Tabel 1 Daftar SPBU beserta data permintaan dan jarak dari Depot SPBU Pertamina 34.401.25 ( Jl. Dipatiukur )

\begin{tabular}{|c|c|l|c|c|}
\hline No & $\begin{array}{c}\text { Kode } \\
\text { SPBU }\end{array}$ & \multicolumn{1}{|c|}{ Alamat } & $\begin{array}{c}\text { Permintaan } \\
\text { (Kiloliter) }\end{array}$ & $\begin{array}{c}\text { Jarak } \\
\text { (Km) }\end{array}$ \\
\hline 1 & 34.401 .02 & $\begin{array}{l}\text { Jl. Wastukencana } \\
\text { No.36 }\end{array}$ & 37 & 3,0 \\
\hline 2 & 34.401 .01 & $\begin{array}{l}\text { Jl. Dr. Setiabudi } \\
\text { No. 362 }\end{array}$ & 19 & 5,0 \\
\hline
\end{tabular}

\begin{tabular}{|c|c|l|c|c|}
\hline No & $\begin{array}{c}\text { Kode } \\
\text { SPBU }\end{array}$ & \multicolumn{1}{|c|}{ Alamat } & $\begin{array}{c}\text { Permintaan } \\
\text { (Kiloliter) }\end{array}$ & $\begin{array}{c}\text { Jarak } \\
\text { (Km) }\end{array}$ \\
\hline 3 & 34.401 .30 & J1. Sunda No. 76 B & 39 & 3,8 \\
\hline 4 & 34.401 .22 & $\begin{array}{l}\text { J1. Ir.H. Juanda } \\
\text { (Dago) No.139 }\end{array}$ & 20 & 2,9 \\
\hline 5 & 34.402 .44 & $\begin{array}{l}\text { J1. AH Nasution } \\
\text { No. 940-944 }\end{array}$ & 14 & 6,6 \\
\hline 6 & 34.401 .21 & $\begin{array}{l}\text { J1. Cihampelas } \\
\text { No.175 }\end{array}$ & 26 & 2,6 \\
\hline 7 & 34.401 .26 & \begin{tabular}{l} 
J1. Rajawali Barat \\
\hline
\end{tabular} \\
\hline
\end{tabular}

Sumber : Pertamina Bandung

2.3.2. Metode Pengumpulan Data

a. Wawancara

Wawancara dilakukan secara langsung dengan manajer dari kantor PT Pertamina Depot Bandung. Wawancara dilakukan secara online dengan menggunakan sosial media WhatsApp tersebut dilakukan saat jam kerja.

b. Dokumentasi

Dokumentasi dilakukan dengan mengumpulkan data - data yang diperlukan bagi penelitian yang akan digunakan dalam perhitungan laporan.

2.3.3. Flow Chart Penelitian

a. Tinjauan Pustaka

Langkah ini dilakukan Penulis untuk mendapatkan data, teori maupun metode yang relevan dengan permasalahan yang ada. Studi literatur ini dilakukan dengan cara mencari metode atau teori dari media buku dan internet. Dalam proses penelitian ini beberapa teori yang dibahas mengenai distribusi, metode saving matriks, dan faktor-faktor penunjang yang lainnya.

b. Identifikasi masalah

Observasi yang sudah dilakukan akan menunjukkan bagian mana yang akan di pilih untuk selesaikan masalahnya. Identifikasi masalah juga akan didukung dengan data - data yang di dapat dari Kantor PT Pertamina Depot Bandung.

c. Pengolahan Data

Data yang sudah diambil akan diolah untuk dipilih data mana yang diperlukan ntuk penelitian ini. Data - data tersebut juga akan diampirkan nantinya di laporan untuk mendukung penelitian. Adapun asumsi dan batasan yang akan di lakukan pada penelitian ini adalah sebagai berikut :

1. Mobil angkutan yang digunakan untuk mendistribusikan BBM ke setiap SPBU adalah trruk tangki dengan muatan $16 \mathrm{kl}$ dan $24 \mathrm{kl}$ masingmasing sebanyak 2 dan 5 truk.

2. Harga bahan bakar adalah $\mathrm{Rp} 1.706 / \mathrm{km}$ untuk yang muatan $16 \mathrm{kl}$ dan $\mathrm{Rp}$ 2.560/km untuk yang muatan $24 \mathrm{kl}$.

3. Setiap kendaraan truk tangki membutuhkan 1 sopir dan 1 kernet 
4. Jarak berdasarkan Google Maps dengan menghindari jalan tol.

d. Analisis Hasil dan Pembahasan

Analisis hasil dan pembahasan ini mulai dari penentuan metode yang akan digunakan untuk menyelesaikan masalah yang ada, studi literature yang dpaat mendukung, pengolahan data - data, perthitungan hingga mendapat hasil untuk penyelesaian masalah yang ada.

2.3.4. Flowchart Metode yang digunakan pada Penelitian

a. Pengambilan data

Data yang akan dipakai untuk mendukung penelitian ini mulai dari permintaan bahan bakar PREMIUM pada setiap SPBU dengan data masa lalu yaitu pada bulan Januari hingga Maret 2020. Data yang kedua yaitu jarak masing - masing SPBU dan Kantor Depot. Data ketiga yaitu data kapasitas untuk setiap alat angkut mobil dan data alat angkut apa saja yang di pakai di PT Pertamina Depot Bandung.

b. Penghitungan Metode Saving Matriks

Perhitungan ini pertama yaitu dengan menghitung matriks jarak berdasarkan jarak antara PT Pertamina Depot dengan SPBU, atau SPBU dan SPBU lainnya. Perhitngan kedua yaitu dengan menghitung matriks jarak dengan metode saving matrix menggunakan matriks jarak sebelumnya. Ketiga yaitu dengan membuat rute dengan memperhitungkan kapasitas yang dapat dimuat dalam alat angkut tersebut. Keempat dengan menghitung total jarak yang akan ditempuh pada setiap rute dan menentukan pola rute yang akan direkomendasikan dengan rute yang terpilih dengan metode nearest neighbor. Kelima yaitu dengan menghitung dengan metode yang berbeda yaitu farthest insertion. Keenam yaitu dengan menghitung jumlah biaya bahan bakar yang akan terpakai pada setiap satu kali pengiriman berdasarkan metode yang dipakai masing - masing.

c. Analisis Hasil dan Pembahasan

Analisis ini akan menunjukkan hasil dari pemilihan rute yang dapat direkomendasikan dengan penghitungan yang ada.

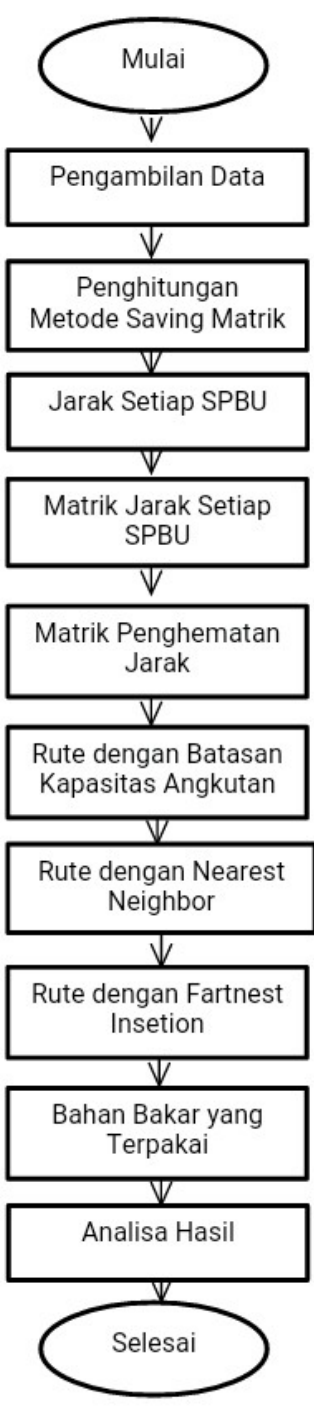

Gambar II. 1 Flowchart Metode

\section{HASIL DAN PEMBAHASAN \\ 3.1. Jarak SPBU Cabang dengan PT Pertamina Depot Bandung}

PT. Pertamina Depot Bandung memiliki wilayah pendistribusian di kota Bandung sebanyak 7 SPBU. Permintaan akan premium setiap harinya sangatlah tinggi dikarenakan begitu penting produk ini di masyarakat. Tabel 1 adalah daftar SPBU di kota Bandung yang disuplai dari Depot Bandung serta data permintaan rata-rata harian premium untuk SPBU di wilayah kota Bandung dan data jarak dari Depot ke tiap SPBU. Moda transportasi yang digunakan PT. Pertamina untuk mendistribusikan BBM ke SPBU adalah truk tangki. Kapasitas truk tangki yang tersedia di perusahaan penyedia armada transportasi pada saat penelitian adalah $16 \mathrm{kl}$ dan $24 \mathrm{kl}$ masing-masing 
sebanyak 2 dan 4 truk. Biaya bahan bakar yang dikeluarkan tergantung dari besarnya kendaraan yang digunakan, makin besar kendaraan maka makin besar pula biaya yang harus dikeluarkan untuk bahan bakar. Besar biaya perkilometer untuk setiap kapasitas bisa dilihat di table 2.

Untuk setiap kendaraan truk tangki membutuhkan 1 sopir dan 1 kernet. Gaji untuk supir dan kernet termasuk biaya tetap yang dimasukkan dalam biaya transportasi pada penelitian ini. Makin banyak jumlah truk tangki yang digunakan maka makin banyak pula jumlah sopir dan kernet yang dibutuhkan, sehingga biaya operasionalnya juga makin tinggi. Tabel 3. adalah data gaji sopir dan kernet truk tangki untuk jumlah hari kerja selama satu bulan sebanyak 25 hari.

Tabel 2 Daftar SPBU beserta Data Permintaan dan jarak dari Depot SPBU Pertamina 34.401.25 (JI Dipatiukur)

\begin{tabular}{|c|c|l|c|c|}
\hline No & $\begin{array}{c}\text { Kode } \\
\text { SPBU }\end{array}$ & \multicolumn{1}{|c|}{ Alamat } & $\begin{array}{c}\text { Permintaan } \\
\text { (Kiloliter) }\end{array}$ & $\begin{array}{c}\text { Jarak } \\
(\mathbf{K m})\end{array}$ \\
\hline 1 & 34.401 .02 & $\begin{array}{l}\text { Jl. } \\
\text { Wastukencana } \\
\text { No.36 }\end{array}$ & 37 & 3.0 \\
\hline 2 & 34.401 .01 & $\begin{array}{l}\text { Jl. Dr. } \\
\text { Setiabudi No. } \\
362\end{array}$ & 19 & 5,0 \\
\hline 3 & 34.401 .30 & $\begin{array}{l}\text { Jl. Sunda No. } \\
76 \text { B }\end{array}$ & 39 & 3,8 \\
\hline 4 & 34.401 .22 & $\begin{array}{l}\text { Jl. } \\
\text { Ir.H.Djuanda } \\
\text { (Dago) No.139 }\end{array}$ & 20 & 2,9 \\
\hline 5 & 34.402 .44 & $\begin{array}{l}\text { Jl. AH } \\
\text { Nasution No. } \\
940-944\end{array}$ & 14 & 6,6 \\
\hline 6 & 34.401 .21 & $\begin{array}{l}\text { Jl. Cihampelas } \\
\text { No.175 }\end{array}$ & 26 & 2,6 \\
\hline 7 & 34.401 .26 & $\begin{array}{l}\text { Jl. Rajawali } \\
\text { Barat }\end{array}$ & 15 & 7,2 \\
\hline
\end{tabular}

Sumber : Pengolahan Hasil Wawancara

\subsection{Biaya Awal Pendistribusian}

Perhitungan total biaya transportasi awal berdasarkan penjumlahan biaya tetap dan biaya variabel. Untuk biaya variabel menggunakan sistem truckload (TL) yag dihitung dari jarak SPBU dari Depot Bandung.

Tabel 3 Data Biaya per Kilometer dari Tiap Kapasitas Truk Tangki

\begin{tabular}{|c|c|c|c|c|c|}
\hline No & $\begin{array}{c}\text { Kap. } \\
\text { Truk }\end{array}$ & Pemakaian & $\begin{array}{c}\text { Harga } \\
\text { BBM }\end{array}$ & JARAK & $\begin{array}{c}\text { Biaya } \\
\text { per KM }\end{array}$ \\
\hline 1 & 16 & 1 liter & 5.120 & 3 & 1.706 \\
\hline 2 & 24 & 1 liter & 5.120 & 2 & 2.560 \\
\hline
\end{tabular}

Sumber : Pengolahan Hasil Wawancara
Tabel 4 Data Gaji Sopir dan Kernet

\begin{tabular}{|c|c|c|c|c|}
\hline No & Posisi & $\begin{array}{c}\text { Gaji perbulan } \\
\text { (Rp) } \\
(\mathbf{A})\end{array}$ & $\begin{array}{c}\text { JUMLAH HARI } \\
\text { OPERASIONAL } \\
\text { DALAM 1 BULAN } \\
\text { (B) }\end{array}$ & $\begin{array}{c}\text { Gaji perhari (Rp) } \\
\text { (A) / (B) }\end{array}$ \\
\hline 1 & Sopir & 2.000 .000 & 25 HARI & 80.000 \\
\hline 2 & Kernet & 2.000 .000 & 25 HARI & 80.000 \\
\hline
\end{tabular}

Sumber : Pengolahan Hasil Wawancara

Rumus perhitungan biaya yaitu sebagai berikut :

Pembagian Tahapan pengiriman

Variabel Cost $=\mathbf{C v} * \mathbf{( 2 d )}$
(1) dengan :
$\mathrm{Cv}=$ Biaya kendaraan per $\mathrm{km}$
$\mathrm{d}=$ Jarak Depot ke SPBU

Fixed Cost $=\mathbf{n} * \mathbf{C f}$

(2) dengan : $\mathrm{n}$ = Jumlah pegawai, $\mathrm{Cf}=$ Gaji Pegawai

Tabel 5 Pembagian Tahapan Pengiriman

\begin{tabular}{|c|c|c|c|c|}
\hline $\begin{array}{l}\text { Kode } \\
\text { SPBU }\end{array}$ & Alamat & $\begin{array}{c}\text { Total } \\
\text { Permintaan } \\
\text { (Kiloliter) } \\
\text { RATA PER } \\
\text { BULAN }\end{array}$ & $\begin{array}{c}\text { Tahap 1 } \\
\text { (kiloliter) }\end{array}$ & $\begin{array}{r}\text { Tahap } 2 \\
\text { (kiloliter) }\end{array}$ \\
\hline 34.401 .02 & $\begin{array}{l}\text { Jl. Wastukencana } \\
\text { No.36 }\end{array}$ & 37 & 24 & 13 \\
\hline 34.401 .01 & $\begin{array}{l}\text { Jl. Dr. Setiabudi No. } \\
362\end{array}$ & 19 & 19 & 0 \\
\hline 34.401 .30 & Jl. Sunda No. 76 B & 39 & 24 & 15 \\
\hline 34.401 .25 & $\begin{array}{l}\text { Jl. Jl. Ir.H.Djuanda } \\
\text { (Dago) No.139 }\end{array}$ & 20 & 20 & 0 \\
\hline 34.402 .44 & $\begin{array}{l}\text { Jl. AH Nasution No. } \\
940-944\end{array}$ & 14 & 14 & 0 \\
\hline 34.401 .21 & $\begin{array}{l}\text { Jl. Cihampelas } \\
\text { No. } 175\end{array}$ & 26 & 24 & 2 \\
\hline 34.401 .26 & Jl. Rajawali Barat & 15 & 15 & 0 \\
\hline
\end{tabular}

Sumber : Pengolahan Data

Tabel 6 Biaya Transportasi Awal Tahap 1

\begin{tabular}{|l|c|c|c|c|c|}
\hline \multicolumn{1}{|c|}{ Alamat } & $\begin{array}{c}\text { Tahap 1 } \\
\text { (kiloliter) }\end{array}$ & $\begin{array}{c}\text { Kap, Truk } \\
\text { Tangki } \\
\text { (Kiloliter) }\end{array}$ & $\begin{array}{c}\text { Biaya/KM } \\
\text { (Rp) }\end{array}$ & $\begin{array}{c}\text { Jarak dari } \\
\text { Depot } \\
\text { (Km) }\end{array}$ & $\begin{array}{c}\text { Biaya Variabel } \\
\text { (Rp) }\end{array}$ \\
\hline $\begin{array}{l}\text { Jl. Wastukencana } \\
\text { No.36 }\end{array}$ & 24 & 24 & 2.560 & 3,0 & 15.360 \\
\hline $\begin{array}{l}\text { Jl. Dr. Setiabudi } \\
\text { No. 362 }\end{array}$ & 24 & 24 & 2.560 & 5,0 & 25.600 \\
\hline $\begin{array}{l}\text { Jl. Sunda No. 76 B } \\
\text { Nl. Ir.H.Djuanda } \\
\text { (Dago) No.139 }\end{array}$ & 24 & 24 & 2.560 & 3,8 & 19.456 \\
\hline $\begin{array}{l}\text { Jl. AH Nasution } \\
\text { No. 940-944 }\end{array}$ & 14 & 16 & 1.706 & 6,6 & 22.519 \\
\hline $\begin{array}{l}\text { Jl. Cihampelas } \\
\text { No.175 }\end{array}$ & 24 & 24 & 2.560 & 2,6 & 13.312 \\
\hline \begin{tabular}{l} 
Jl. Rajawali Barat \\
\hline
\end{tabular} & 15 & 16 & 1.706 & 7,2 & 24.225 \\
\hline
\end{tabular}

Sumber : Pengolahan Data 
Menghitung biaya variable Tahap 1 setiap SPBU :

- Jl. Jl. Wastukencana No.36 :

$$
\begin{aligned}
\text { Variabel Cost } & =\mathrm{Cv} *(2 \mathrm{~d}) \\
& =2.560 \times(2 \times 3,0) \\
& =\mathrm{Rp} 15.360
\end{aligned}
$$

- Jl. Dr. Setiabudi No. 362 :

$$
\begin{aligned}
\text { Variabel Cost } & =\mathrm{Cv} *(2 \mathrm{~d}) \\
& =2.560 \times(2 \times 5,0) \\
& =\mathrm{Rp} 25.600
\end{aligned}
$$

- Jl. Sunda No. 76 B :

$$
\begin{aligned}
\text { Variabel Cost } & =\mathrm{Cv} *(2 \mathrm{~d}) \\
& =2.560 \times(2 \times 3,8) \\
& =\mathrm{Rp} 19.456
\end{aligned}
$$

- Jl. Ir.H.Djuanda No.139 :

$$
\begin{aligned}
\text { Variabel Cost } & =\mathrm{Cv} *(2 \mathrm{~d}) \\
& =2.560 \times(2 \times 2,9) \\
& =\mathrm{Rp} 14.848
\end{aligned}
$$

- Jl. AH Nasution No. 940-944 :

$$
\text { Variabel Cost }=\mathrm{Cv} *(2 \mathrm{~d})
$$$$
=1.706 \times(2 \times 6,6)
$$$$
=\mathrm{Rp} 22.519
$$

- Jl. Cihampelas No.175 :

$$
\begin{aligned}
\text { Variabel Cost } & =\mathrm{Cv} *(2 \mathrm{~d}) \\
& =2.560 \times(2 \times 2,6) \\
& =\mathrm{Rp} 13.312
\end{aligned}
$$

- Jl. Rajawali Barat :

$$
\begin{aligned}
\text { Variabel Cost } & =\mathrm{Cv} *(2 \mathrm{~d}) \\
& =1.706 \times(2 \times 7,2) \\
& =\operatorname{Rp} 24.225
\end{aligned}
$$

Tabel 7 Biaya Transportasi Tahap 2

\begin{tabular}{|l|c|c|c|c|c|}
\hline \multicolumn{1}{|c|}{ Alamat } & $\begin{array}{c}\text { Tahap 2 } \\
\text { (kiloliter) }\end{array}$ & $\begin{array}{c}\text { Kap, } \\
\text { Truk } \\
\text { Tangki } \\
\text { (Kiloliter) }\end{array}$ & $\begin{array}{c}\text { Biaya/KM } \\
\text { (Rp) }\end{array}$ & $\begin{array}{c}\text { Jarak } \\
\text { dari } \\
\text { Depot } \\
\text { (Km) }\end{array}$ & $\begin{array}{c}\text { Biaya } \\
\text { Variabel } \\
\text { (Rp) }\end{array}$ \\
\hline $\begin{array}{l}\text { J1. } \\
\begin{array}{l}\text { Wastukencana } \\
\text { No.36 }\end{array}\end{array}$ & 13 & 16 & 1.706 & 3,0 & 10.236 \\
\hline $\begin{array}{l}\text { J1. Sunda No. } \\
\text { 76 B }\end{array}$ & 15 & 16 & 1.706 & 3,8 & 12.965 \\
\hline $\begin{array}{l}\text { J1. Cihampelas } \\
\text { No.175 }\end{array}$ & 2 & 16 & 1.706 & 2,6 & 8.871 \\
\hline \multicolumn{5}{|l}{ JUMLAH } & $\mathbf{3 2 . 0 7 2}$ \\
\hline
\end{tabular}

Menghitung biaya variable Tahap 2 setiap SPBU :

- Jl. Wastukencana No.36 :

$$
\begin{aligned}
\text { Variabel Cost } & =\mathrm{Cv} *(2 \mathrm{~d}) \\
& =1.706 \times(2 \times 3,0) \\
& =\text { Rp. } 10.236
\end{aligned}
$$

- Jl. Sunda No. 76 B :

$$
\begin{aligned}
\text { Variabel Cost } & =\mathrm{Cv} *(2 \mathrm{~d}) \\
& =1,706 \times(2 \times 3,8) \\
& =\text { Rp. } 12.965
\end{aligned}
$$

- Jl. Cihampelas No.175 :

$$
\begin{aligned}
\text { Variabel Cost } & =\mathrm{Cv} *(2 \mathrm{~d}) \\
& =1,706 \times(2 \times 2,6)
\end{aligned}
$$

$=$ Rp. 8.871

Tabel 8 Penggunaan Awal Kendaraan Truk Tangki

\begin{tabular}{|l|c|c|c|c|}
\hline \multicolumn{2}{|c|}{ Kendaraan } & $\begin{array}{c}\text { Jumlah } \\
\text { Awal }\end{array}$ & Pemakaian & Antrian \\
\hline Premium & $\begin{array}{c}16 \\
\text { KL }\end{array}$ & 2 & 5 & 3 \\
\hline Premium & $\begin{array}{r}24 \\
\text { KL }\end{array}$ & 4 & 5 & 1 \\
\hline \multicolumn{2}{|c|}{ Jumlah } & 6 & $\mathbf{1 0}$ & $\mathbf{4}$ \\
\hline
\end{tabular}

Sumber : Pengolahan Data

Karena jumlah sopir dan kernet yaitu berjumlah 6 orang sopir dan 6 orang kernet. Sehingga biaya tetap berupa gaji sopir-kernet pun diketahui. Sehingga perhitungan biaya transportasi yaitu sebagai berikut :

$$
\begin{aligned}
& \text { Total Biaya Variabel } \quad=\text { Rp } 167.392 \\
& \text { Total Biaya Tetap } \quad=\text { Rp } 480.000 \\
& \text { Total Biaya Tetap } \quad=(6 \text { sopir }+6 \\
& \text { kernet }) \text { xp } 80.000=\text { Rp 960.000 } \\
& \text { Sehingga Total Transportasi } \\
& =\text { Total Biaya Variabel }+ \text { Total Biaya Tetap } \\
& =\text { Rp 167.392 + Rp 960.000 = Rp 1.127.392,- }
\end{aligned}
$$

Perhitungan jarak pada kondisi awal ini berdasarkan jarak dari Depot ke masing-masing SPBU. Dikarenakan sistem pendistribusian yang digunakan yaitu direct shipment maka jarak dari Depot ke SPBU dikalikan dua karena jarak pulang-pergi. Total jarak yang dihasilkan pada rute awal ini adalah sebanyak 81 kilometer. Jarak pada rute awal tersebut dinilai terlalu panjang dan harus dipangkas agar tidak menimbulkan waktu pengiriman yang lama dan biaya transportasi yang tinggi.

\section{Tabel 9 Rute Awal dan Jarak}

\begin{tabular}{ccc}
\hline No & Konsumen & Jarak ( Km) \\
\hline 1 & G-A-G & 6 \\
2 & G-B-G & 10 \\
3 & G-C-G & 7,6 \\
4 & G-D-G & 5,8 \\
5 & G-E-G & 13,2 \\
6 & G-F-G & 5,2 \\
7 & G-G-G & 14,2 \\
8 & G-A-G & 6 \\
9 & G-C-G & 7,6 \\
10 & G-F-G & 5,2 \\
\hline
\end{tabular}

Permintaan premium yang cukup tinggi oleh beberapa SPBU di kota Bandung menyebabkan penjadwalan distribusi premium tidak bisa dilakukan dalam satu kali 
pengiriman karena terbatasnya kapasitas truk tangki yang ada. Oleh karena itu dibutuhkan beberapa kali tahapan pengiriman untuk memenuhi semua kebutuhan premium di semua SPBU. Pengiriman premium untuk setiap SPBU harus dibagi dalam beberapa tahapan bergantung dari kapasitas truk tangki, dikarenakan kapasitas truk tangki adalah kelipatan 8KL, maka pembagian tahapan pengiriman premium tersebut juga dibagi tiap $8 \mathrm{KL}$ untuk setiap tahapannya, dan untuk tahap terakhir dari setiap SPBU dilakukan pengecualian yaitu tidak harus 8KL karena tergantung dari sisa permintaan yang belum dikirim. Sehingga permintaan premium dibagi dalam 3 tahapan pengiriman, yaitu sebagai berikut :

Total Permintaan dibagi $=170$ kiloliter ; menjadi,

Permintaan Tahap $1=56$ kiloliter

Permintaan Tahap $2=56$ kiloliter

Permintaan Tahap $3=58$ kiloliter
Tabel 11 ini merupakan matriks jarak setelah dilakukan perhitungan dengan menggunakan metode saving matrix dengan salah satu contoh sebagai berikut:

$\mathrm{S}(\mathrm{SPBU} 1, \mathrm{SPBU} 2)=3,0+5,0-5,1=2,9$

Tabel 12 Perhitungan Metode Saving Matriks

\begin{tabular}{|c|c|c|c|c|c|c|}
\hline 1 & 2 & 3 & 4 & 5 & 6 & 7 \\
\hline 1 & 2,9 & 4,5 & 3,5 & 2,1 & 1,3 & 4,7 \\
\hline 2 & & 2,5 & 4,5 & 1,6 & 5,6 & 4,5 \\
\hline 3 & & & 2,8 & 4,6 & 0,1 & 3,8 \\
\hline 4 & & & & 2,2 & 3,3 & 2,5 \\
\hline 5 & & & & & 0 & 1,8 \\
\hline 6 & & & & & & 3,6 \\
\hline 7 & & & & & & \\
\hline
\end{tabular}

Tabel 10 Pembagian Awal Tahapan Pengiriman

Tabel 13 Hasil Pengurutan Tahap 1,2 dan 3

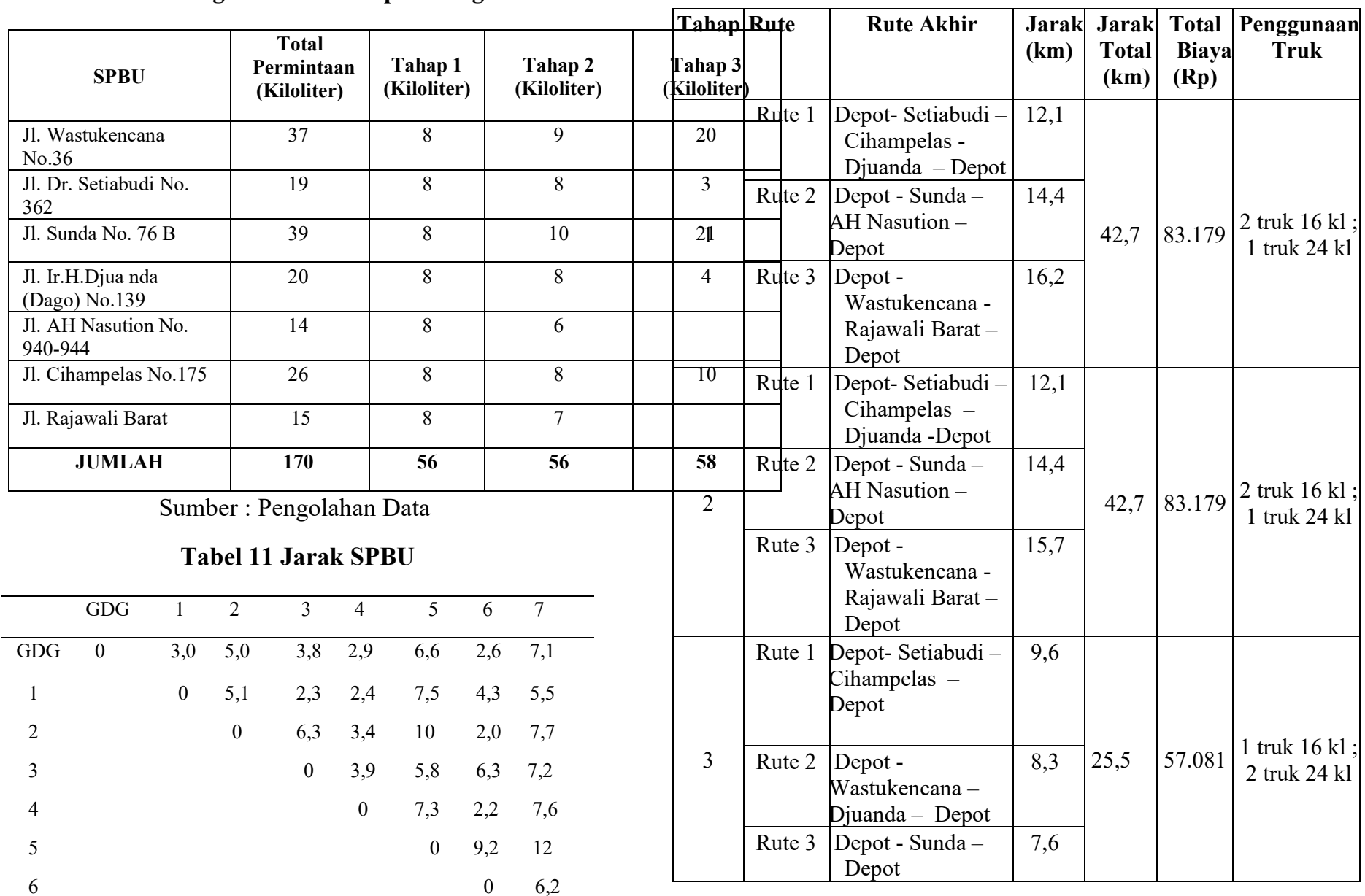




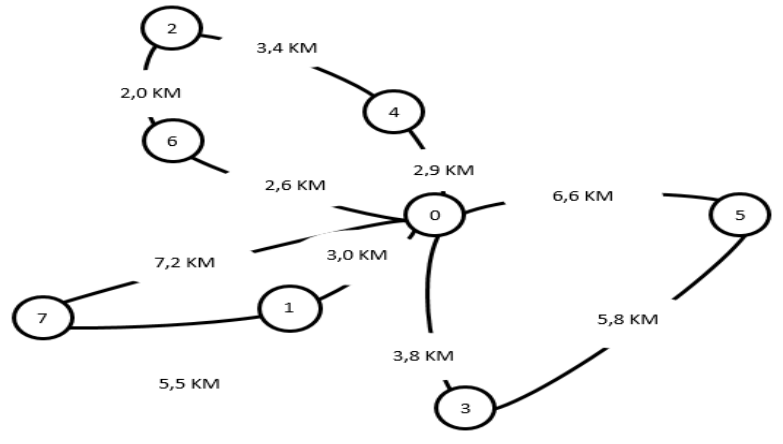

\section{Gambar 1 Rute Terbaik Tahap 1 dengan Metode Saving Matriks}

Gambar 1 merupakan gambar tahap 1 dengan menggunakan Saving Matriks. Rute 1 dilakukan terlebih dahulu dari Depot ke SPBU no $4 \rightarrow 2 \rightarrow 6$ dengan jumlah BBM yang diangkut adalah $24 \mathrm{KL}$ dan jarak total $12,1 \mathrm{KM}$. Selanjutnya rute 2 dilakukan dari Depot ke SPBU no $3 \rightarrow$ 5 dengan jumlah BBM yang diangkut adalah $16 \mathrm{KL}$ dan jarak total 14,4. Kemudian rute 3 dilakukan dari Depot ke SPBU no $1 \rightarrow 7$ dengan jumlah BBM yang diangkut adalah $16 \mathrm{KL}$ dan jarak total 16,2. Sehingga total jarak pada tahap 1 adalah $42,7 \mathrm{KM}$ dan total biaya yang dikeluarkan $\mathrm{Rp}$ $83.179,-$.

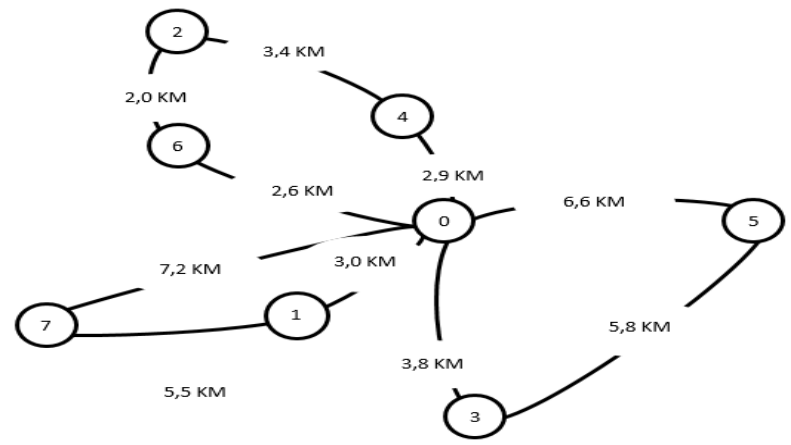

\section{Gambar 2 Rute Terbaik Tahap 2 dengan Metode Saving Matriks}

Gambar 2 merupakan gambar tahap 2 dengan menggunakan Saving Matriks. Rute 1 dilakukan terlebih dahulu dari Deopot ke SPBU no $4 \rightarrow 2 \rightarrow 6$ dengan jumlah BBM yang diangkut adalah $24 \mathrm{KL}$ dan jarak total $12,1 \mathrm{KM}$. Selanjutnya rute 2 dilakukan dari Depot ke SPBU no $3 \rightarrow$ 5 dengan jumlah BBM yang diangkut adalah $16 \mathrm{KL}$ dan jarak total 14,4. Kemudian rute 3 dilakukan dari Depot ke SPBU no $1 \rightarrow 7$ dengan jumlah BBM yang diangkut adalah $16 \mathrm{KL}$ dan jarak total 16,2 . Sehingga total jarak pada tahap 2 adalah $42,7 \mathrm{KM}$ dan total biaya yang dikeluarkan Rp $83.179,-$.

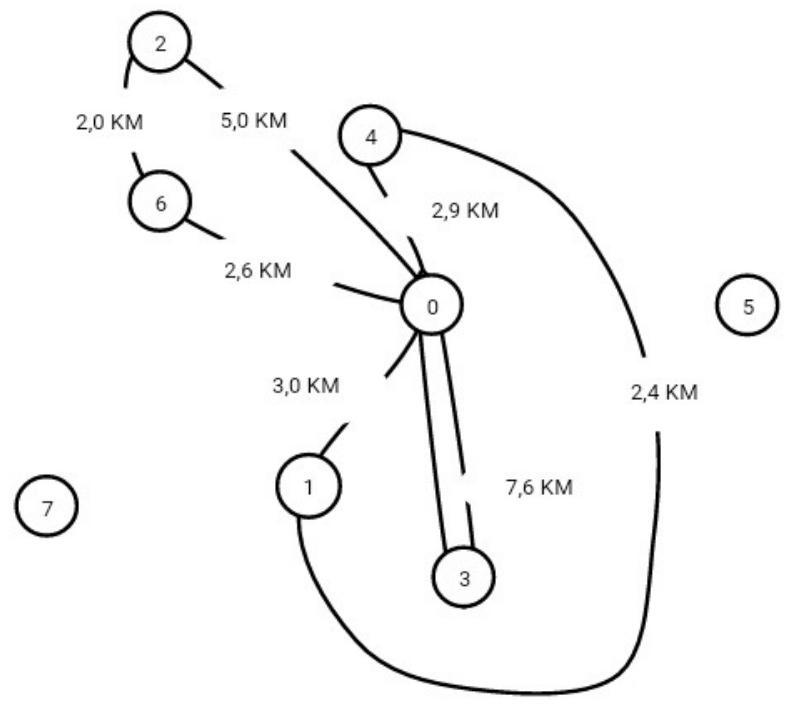

\section{Gambar 3 Rute Terbaik Tahap 3 dengan Metode Saving Matriks}

Gambar 3 merupakan gambar tahap 3 dengan menggunakan Saving Matriks. Rute 1 dilakukan terlebih dahulu dari Deopot ke SPBU no $2 \rightarrow 6$ dengan jumlah BBM yang diangkut adalah $13 \mathrm{KL}$ dan jarak total 9,6 KM. Selanjutnya rute 2 dilakukan dari Depot ke SPBU no $1 \rightarrow$ 5 dengan jumlah BBM yang diangkut adalah $24 \mathrm{KL}$ dan jarak total 8,3. Kemudian rute 3 dilakukan dari Depot ke SPBU no 3 dengan jumlah BBM yang diangkut adalah 21 KL dan jarak total 7,6. Sehingga total jarak pada tahap 2 adalah $25,5 \mathrm{KM}$ dan total biaya yang dikeluarkan $\mathrm{Rp}$ $57.081,-$.

\subsection{Jumlah Penggunaan Kendaraan}

Salah satu hasil dari penentuan rute dengan saving matrix adalah rencana jumlah truk tangki yang seharusnya digunakan beserta kapasitasnya.

Tabel 14 Penggunaan Akhir Kendaraan Truk Tangki

\begin{tabular}{|c|c|c|c|c|c|c|}
\hline \multicolumn{2}{|c|}{ Kendaraan } & $\begin{array}{c}\text { Jml } \\
\text { Awal }\end{array}$ & $\begin{array}{c}\text { Pema- } \\
\text { kaian }\end{array}$ & $\begin{array}{c}\text { Keb. } \\
\text { Tahap } \\
\text { 1 }\end{array}$ & $\begin{array}{c}\text { Keb. } \\
\text { Tahap } \\
\mathbf{2}\end{array}$ & $\begin{array}{c}\text { Keb. } \\
\text { Tahap } \\
\mathbf{3}\end{array}$ \\
\hline Premium & $\begin{array}{r}16 \\
\text { KL }\end{array}$ & 2 & 5 & 2 & 2 & 1 \\
\hline Premium & $\begin{array}{r}24 \\
\text { KL }\end{array}$ & 4 & 4 & 1 & 1 & 2 \\
\hline \multicolumn{2}{|c|}{ Jumlah } & $\mathbf{6}$ & & $\mathbf{3}$ & $\mathbf{3}$ & $\mathbf{3}$ \\
\hline
\end{tabular}

\subsection{Perhitungan Biaya Transportasi}

Biaya transportasi yang dibutuhkan untuk mendistribusikan premium dalam 10 rute tersebut yaitu.

Total Biaya Tetap untuk gaji sopir dan kernet :

$$
=(4 \times \operatorname{Rp} 80.000)+(4 \times \operatorname{Rp} 80.000)
$$




$$
\begin{aligned}
& =\operatorname{Rp} 640.000,- \text { /hari } \\
& \text { Total Biaya Transportasi } \\
& =\text { Total Biaya Variabel + Total Biaya Tetap } \\
& =\text { Rp } 223.439+\text { Rp } 640.000 \\
& =\operatorname{Rp~} 863.439,- \text { /hari }
\end{aligned}
$$

\section{Tabel 15 Perbandingan Hasil Perhitungan}

\begin{tabular}{|c|l|c|c|}
\hline No & Faktor Pembanding & Nilai Awal & Nilai Akhir \\
\hline 1 & Jarak tempuh & $81 \mathrm{Km}$ & $110,9 \mathrm{Km}$ \\
\hline 3 & $\begin{array}{l}\text { Kebutuhan Jumlah } \\
\text { Kendaraan }\end{array}$ & 6 truk tangki & 4 truk tangki \\
\hline 4 & Pemakaian Kendaraan & 10 kali & 9 kali \\
\hline 5 & $\begin{array}{l}\text { Biaya Transportasi per } \\
\text { hari }\end{array}$ & Rp 1.127.392,- & Rp 861.733,- \\
\hline
\end{tabular}

\section{KESIMPULAN}

Metode saving matrix menghasilkan efisiensi dalam hal kebutuhan jumlah kendaraan sebanyak 2 truk tangki, pemakaian kendaraan satu kali dan biaya transportasi per hari sebesar Rp. 265.659,-

\section{REFERENSI}

Bowersox, J. (2006). Logistik supply Chain Management,. 1st Edition, McGraw-Hill Higher.

Daryanto. (2011). Manajemen Pemasaran. Bndung: PT Sarana Tutorial Nurani .

Gunawan , D. I. (2010). Penentuan Distribusi. Surabaya: UPN "Veteran".

Hutabarat, J. (2008). Penentuan jalur distribusi pada rantai supply.

Ikfan, N., \& Masudin, I. (2014). Saving matrix untuk menentukan rute distribusi. Jurnal Ilmiah Teknik Industri, 14 - 17.

Istantiningrum, M. (2010). Penentuan Rute. Pengiriman dan Penjadwalan Dengan Menggunakan Metode Saving Matrix Study Kasus Pada PT. Sukanda Djaya Yogyakarta.

Kotler, P. (2000). Manajemen Pemasaran . Jakarta : Erlangga .
Parwati1, C. I., \& Neto , J. E. (2008). Efektivitas distribusi produk dalam rantai pasok.

Pujawan. (2006). Supply Chain Management. Surabaya: Guna Widya.

Rahayu , S., \& Yuliana, P. E. (2008). Perencanaan jadwal dan penentuan rute distribusi.

Subagyo. (2000). Dasar - Dasar Operation Research. Yogyakarta : BPFE UGM .

Suntoyo. (2013). Prosedur Saluran Distribusi. Prosedur Saluran Distribusi, 175.

Supriadi, S. K. (2017). (Supriyadi, Supriyadi, Kholil Mawardi, and Ahmad Nalhadi. "Minimasi Biaya Dalam Penentuan Rute Distribusi Produk Minuman Menggunakan Metode Savings Matrix." Prosiding Seminar Nasional Riset Terapan|. SENASSET.

Swasta. (2012). Manajemen Penjualan, Edisi 3, Yogyakarta, BPFE. 